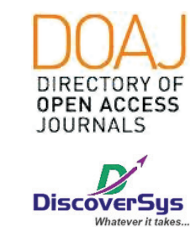

Published by DiscoverSys

\section{Isolasi bakteri Escherichia coli pada lawar merah babi di kota Denpasar}

\author{
Dennis Yulianto, ${ }^{1 *} \mid$ Dewa Sukrama, ${ }^{2}$ Made Agus Hendrayana ${ }^{2}$
}

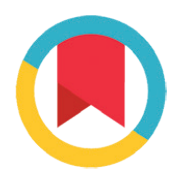

CrossMark

\title{
ABSTRACT
}

Background: An alarming incidence rate of food-borne diseases in Indonesia become more worrible, especially the one which is caused by Escherichia coli. Based on Food and Drug Supervisory Agency or Badan Pengawas Obat dan Makanan (BPOM) in Indonesia, there are 18.144 people who got infected by food-borne illnesses in 2011. These facts are quite alarming for the people who live in Bali and they are more likely to consume lawar merah babi. Lawar merah babi is a traditional Balinese food made from the mix of vegetable, meat, and some other ingredients as well as it is usually mixed by hand which make it susceptible to be contaminated by bacteria such as Escherichia coli. Aim: The study aims to investigate the $E$. coli contamination within lawar merah in Denpasar.

Method: This descriptive cross-sectional study was conducted using 12 samples of lawar merah babi which were sold in 12 different places all across the Denpasar City. These samples were taken to Microbiology Laboratorium at Medical Faculty, Udayana University. There are three variants of dilution for each sample which are $10^{-1}, 10^{-2}$, and $10^{-3}$. Each sample was cultured using eosin methylene blue agar as the media. Some of the sample without clear representation in the media will go through further identification. The results of Escherichia coli colonization were counted by the total plating count method to produce them in CFU/g for each of the samples.

Result: Some of the samples have been contaminated by Escherichia coli (67\%) approximately $17 \times 10^{4}$ CFU/g contamination average level. Conclusion: The samples exceed the contamination limit which is permitted by the BPOM recommendation, where the maximum Escherichia coli contamination level should not exceed over than 3 $\mathrm{CFU} / \mathrm{g}$.

Keyword: lawar merah babi, Escherichia coli, food borne illnesses

Cite This Article: Yulianto, D., Sukrama, I.D., Hendrayana, M.A. 2019. Isolasi bakteri Escherichia coli pada lawar merah babi di kota Denpasar. Intisari Sains Medis 10(1): 53-56. D0I: 10.1556/ism.v10i1.238

\section{ABSTRAK}

Angka insidens food-borne diseases semakin mengkhawatirkan di Indonesia, terutama yang disebabkan oleh Escherichia coli. Berdasarkan data Badan Pengawas Obat dan Makanan (BPOM) di Indonesia, terdapat total 18.144 orang yang terinfeksi oleh penyakit ini pada tahun 2011. Fakta-fakta ini cukup mengkhawatirkan bagi orang-orang yang tinggal di Bali yang lebih cenderung mengkonsumsi lawar merah babi. Lawar merah babi adalah makanan tradisional Bali yang terbuat dari campuran sayuran, daging dan beberapa bahan lain yang biasanya dicampur dengan tangan yang membuatnya rentan terkontaminasi oleh bakteri seperti Escherichia coli.

'Program Studi Pendidikan Dokter, Fakultas Kedokteran, Universitas Udayana

${ }^{2}$ Departemen Mikrobiologi Klinik Fakultas Kedokteran, Universitas Udayana, RSUP Sanglah Denpasar

${ }^{*}$ Corresponding: Dennis Yulianto, Program Studi Pendidikan Dokter, Fakultas Kedokteran, Universitas Udayana

dennisyuliant096@gmail.com

Metode: Penelitian deskriptif cross-sectional ini dilakukan menggunakan

12 sampel lawar merah babi yang dijual di 12 tempat berbeda di seluruh

Kata kunci: lawar merah babi, Escherichia coli, food borne illnesses Sains Medis 10(1): 53-56. D0l: 10.1556/ism.v10i1.238

\section{PENDAHULUAN}

Food borne illnesses didefinisikan oleh World Health Organization sebagai penyakit infeksi atau kota Denpasar. Sampel ini di periksa di Laboratorium Mikrobiologi di Fakultas Kedokteran Universitas Udayana. Ada tiga varian pengenceran untuk setiap sampel yaitu 10-1, 10-2, dan 10-3. Setiap sampel dikultur menggunakan eosin methylene blue agar sebagai media. Beberapa sampel tanpa representasi yang jelas di media akan melalui identifikasi lebih lanjut. Hasil kolonisasi Escherichia coli dihitung dengan metode total plating count dalam unit CFU/g untuk masing-masing sampel. Hasil: Beberapa sampel lawar babi telah terkontaminasi oleh Escherichia coli (67\%) dengan tingkat kontaminasi rata-rata 17x104 CFU/g.

Simpulan: Sampel melebihi batas kontaminasi makanan yang diizinkan oleh BPOM, di mana kontaminasi Escherichia coli maksimum tidak lebih dari $3 \mathrm{CFU} / \mathrm{g}$.

Cite Pasal Ini: Yulianto, D., Sukrama, I.D., Hendrayana, M.A. 2019. Isolasi bakteri Escherichia coli pada lawar merah babi di kota Denpasar. Intisari

toksik alamiah yang bisa disebabkan oleh terkontaminasinya makanan atau minuman. Food borne 
illnesses diklasifikasikan menjadi dua grup besar yaitu infeksi dan intoksikasi. Intoksikasi disebabkan oleh masuknya toksin yang dihasilkan patogen kedalam tubuh, sedangkan infeksi disebabkan oleh masuknya patogen hidup yang terkandung didalam makanan kedalam tubuh. ${ }^{1}$ Food borne illnesses merupakan salah satu problematika kesehatan yang perlu diperhatikan sendiri. Angka kejadian di Indonesia menurut Badan Pengawas Obat dan Makanan (BPOM) mencapai 128 kasus kejadian luar biasa food borne ilnesses dan ada 18.144 orang yang terpapar food borne illnesses yang tercatat pada tahun 2011. ${ }^{2}$ Food borne ilnesses pun merupakan sebuah fenomena gunung es dikarenakan tidak semua kasus kejadian dapat terlaporkan. Menurut WHO, keracunan pangan di negara berkembang, terdapat 99 kasus yang tidak terlaporkan. ${ }^{2}$ Oleh karena itu, Indonesia sebagai negara berkembang perlu melakukan peningkatan pencegahan terhadap kejadian luar biasa food borne ilnesses dengan melakukan pengawasan terhadap makananmakanan yang beredar masih sesuai dengan batas aman yang ditetapkan oleh BPOM.

Escherichia coli merupakan bakteri gram negatif, jika diamati dengan menggunakan mikroskop akan berwarna merah muda jika telah dilakukan pengecatan gram, $\pm 3 \mu \mathrm{m}$, bentuk batang tunggal atau ganda, motil, fakultatif anaerobik. Escherichia coli jika dikultur akan memiliki warna merah muda pada agar MacConkey, koloni hijau kekuningan pada agar Blood Agar (BG), dan berwarna hijau mengkilap pada agar Eosin Methylene Blue (EMB). ${ }^{1,3}$ Escherichia coli tumbuh optimal pada suhu $10^{\circ} \mathrm{C}-45^{\circ} \mathrm{C}$, dan dapat tumbuh pada $\mathrm{pH}$ seki$\operatorname{tar} 5-7,5$. Escherichia coli juga mampu bertumbuh pada media yang mengandung $\mathrm{NaCl}$ konsentrasi 0.5-5\%. ${ }^{4}$ Menurut CDC Escherichia coli memiliki 5 jenis yaitu Enterohemorrhagic E. coli (EHEC), Enterotoxigenic E.coli (ETEC), Enteropathogenic E.coli (EPEC), Enteroaggregative E. coli (EAEC), dan Enteroinvasive E. coli (EIEC). ${ }^{5}$ Setiap jenis ini akan berdampak berbeda terhadap penyakit tertentu pada manusia. Lawar Bali merupakan makanan khas Bali yang sangat digemari oleh masyarakat lokal dan wisatawan. Lawar Bali merupakan olahan daging atau sayuran cincang yang memungkinkan terjadinya kontaminasi bakteri karena dalam pengolahannya yang pada umumnya menggunakan tangan kosong. Lawar Bali ada dua jenis, yaitu lawar merah yang mengandung darah segar dan lawar putih yang tidak mengandung darah. ${ }^{6}$ Lawar biasanya hanya didiamkan di suhu ruangan dan tanpa dimasak, hal ini yang memungkinkan lawar akan cepat basi dan memudahkan pertumbuhan bakteri. Lawar banyak dijual di pulau Bali, salah satunya kota Denpasar. Menurut beberapa studi, lawar merah dapat menyebabkan kejadian luar biasa. Berdasarkan keadaan diatas, maka peneliti perlu untuk melakukan penelitian yang bertujuan untuk mengetahui tingkat kontaminasi Escherichia Coli pada lawar merah di kota Denpasar. ${ }^{7}$ Pendeteksian bakteri Escherichia coli pada lawar merah bisa dilakukan dengan kultur namun perlu juga dilakukan uji katalase, uji koagulase, dan uji fermentasi agar kita bisa memastikan bakteri yang tumbuh sesuai dengan ciri-ciri Escherichia coli atau bakteri lain yang bisa juga hidup di agar MacConkey. ${ }^{3,8}$ Selain dengan teknik kultur, identifikasi bakteri dapat dilakukan dengan menggunakan alat VITEK 2. Kelebihan VITEK 2 ini cepat dalam memberikan hasil identifikasi bakteri hanya dalam waktu 3 sampai 7 jam. ${ }^{9}$

\section{METODE PENELITIAN}

Penelitian digunakan adalah observasional deskriptif dengan rancangan penelitian cross-sectional untuk mengetahui kontaminasi pada lawar merah babi terhadap Escherichia coli di Kota Denpasar. Sampel penelitian ini adalah sampel lawar merah babi dari penjual di warung makan di kota Denpasar. Instrumen yang digunakan pada penelitian ini tabung reaksi, ose, mikropipet, cawan petri, bunsen, timbangan digital, akuades, Eosin Methylene Blue Agar, Triptic Soy Broth, dan kertas tisu. Penelitian dilakukan 2 kali dengan setiap penelitian diperiksa 6 buah sampel. Sampel tersebut akan ditimbang dengan berat 1 gram dan lalu dimasukkan kedalam botol yang berisi akuades sebanyak $9 \mathrm{ml}$ sehingga diperoleh pengenceran $10^{-1}$. Berikutnya, sebanyak $1 \mathrm{ml}$ dari suspensi pengenceran $10^{-1}$ diambil menggunakan pipet lalu dimasukkan ke dalam tabung reaksi yang berisi $9 \mathrm{ml}$ air steril sehingga diperoleh pengenceran $10^{-2}$. Selanjutnya diambil $1 \mathrm{ml}$ dari suspensi pengenceran $10^{-2}$ menggunakan pipet untuk kemudian diteteskan ke tabung reaksi lain untuk mendapatkan pengenceran $10^{-3}$ lalu dihomogenkan dan diambil cairan $1 \mathrm{ml}$ untuk dibuang sehingga jumlah cairan pada tabung reaksi berjumlah $9 \mathrm{ml}$. Ambil 10 mikroliter dari sampel yang telah diencerkan, dan teteskan pada media Eosin Methylene Blue sesuai dengan label dan pengenceran yang telah ditentukan, lalu dilakukan striking pada empat (4) kuadran dan diinkubasikan pada suhu $35-37^{\circ} \mathrm{C}$ selama $18-24$ jam. Hasil koloni Escherichia coli dari setiap sampel dibandingkan dengan batas maksimum kontaminasi Escherichia coli pada makanan yang ditetapkan oleh BPOM (maksimal kontaminasi $3 \mathrm{CFU} / \mathrm{g}$ ) kemudian dianalisa menggunakan statistik deskriptif yang disajikan dalam bentuk narasi dan tabel. 


\section{HASIL}

Hasil penelitian menunjukkan bahwa 11 cawan petri dengan pertumbuhan bakteri dan 25 cawan petri tidak dengan pertumbuhan bakteri. Sebelas cawan petri dengan pertumbuhan koloni sebagai berikut cawan L1 $10^{-1}$, cawan L2 $10^{-1}$, cawan L2 $10^{-2}$, cawan L4 $10^{-2}$, cawan L5 $10^{-1}$, cawan L6 $10^{-1}$, cawan L7 $10^{-1}$, cawan L7 $10^{-2}$, cawan L10 $10^{-1}$, cawan L10 $10^{-2}$, dan cawan L12 $10^{-3}$. Koloni yang terbentuk ukuran nya bervariasi ada yang diameter nya $1 \mathrm{~mm}$ dan ada koloni dengan diameter $3 \mathrm{~mm}$. Data yang disajikan pada tabel 1 menunjukkan hasil pengamatan sampel yang tumbuh pada media agar eosin methylene blue.

\section{Tabel 1 Hasil Pengamatan Kultur Lawar Merah Babi Pada Eosin Methylene Blue Agar}

\begin{tabular}{lcccl}
\hline & \multicolumn{3}{c}{$\begin{array}{c}\text { Jumlah Koloni PadaVariasi } \\
\text { Pengenceran }\end{array}$} & \\
\cline { 2 - 4 } No. Sampel & $\mathbf{1 0}^{-1}$ & $\mathbf{1 0}^{-2}$ & $\mathbf{1 0}^{-3}$ & Gambaran Koloni \\
\hline L1 & 2 & 0 & 0 & Bulat hijau mengkilap \\
L2 & 1 & 3 & 0 & Bulat hijau mengkilap \\
L3 & 0 & 0 & 0 & Tidak terbentuk koloni \\
L4 & 0 & 2 & 0 & Bulat hijau mengkilap \\
L5 & 0 & 1 & 0 & Bulat hijau mengkilap \\
L6 & 1 & 0 & 0 & Bulat hijau mengkilap \\
L7 & 1 & 2 & 0 & Bulat hijau mengkilap \\
L8 & 0 & 0 & 0 & Tidak terbentuk koloni \\
L9 & 0 & 0 & 0 & Tidak terbentuk koloni \\
L10 & 1 & 2 & 0 & Bulat hijau mengkilap \\
L11 & 0 & 0 & 0 & Tidak terbentuk koloni \\
L12 & 0 & 0 & 2 & Bulat hijau mengkilap \\
\hline
\end{tabular}

Tabel 2 Hasil perhitungan jumlah koloni dalam CFU/g dan status kontaminasi setiap sampel lawar merah babi

\begin{tabular}{lcc}
\hline No & Jumlah Koloni & Status \\
\hline L1 & $2 \times 10^{4} \mathrm{CFU} / \mathrm{g}$ & Terkontaminasi \\
L2 & $1 \times 10^{4} \mathrm{CFU} / \mathrm{g}$ & Terkontaminasi \\
L3 & - & - \\
L4 & $2 \times 10^{5} \mathrm{CFU} / \mathrm{g}$ & Terkontaminasi \\
L5 & $1 \times 10^{5} \mathrm{CFU} / \mathrm{g}$ & Terkontaminasi \\
L6 & $1 \times 10^{4} \mathrm{CFU} / \mathrm{g}$ & Terkontaminasi \\
L7 & $1 \times 10^{4} \mathrm{CFU} / \mathrm{g}$ & Terkontaminasi \\
L8 & - & - \\
L9 & - & - \\
L10 & $1 \times 10^{4} \mathrm{CFU} / \mathrm{g}$ & Terkontaminasi \\
L11 & - & - \\
L12 & $1 \times 10^{6} \mathrm{CFU} / \mathrm{g}$ & Terkontaminasi \\
\hline
\end{tabular}

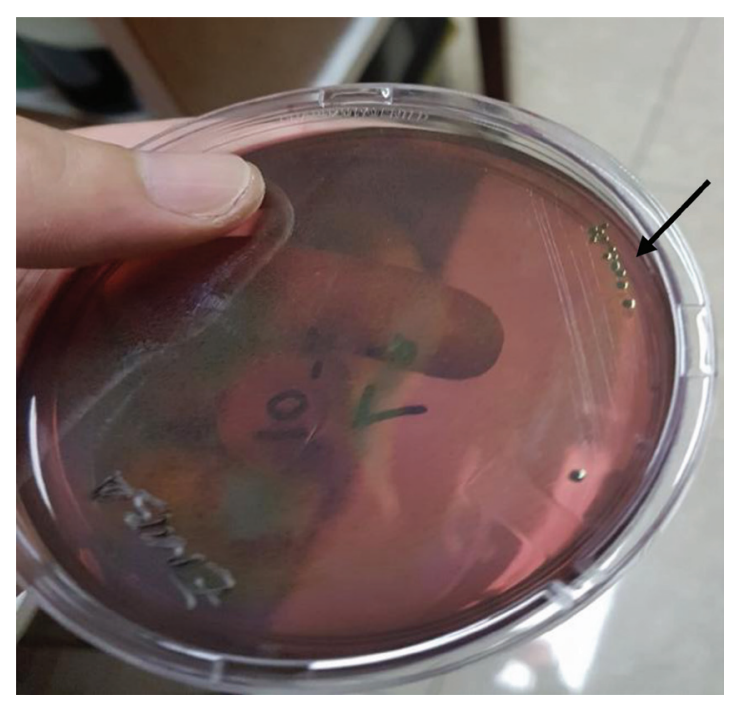

Gambar 1 Koloni bulat hijau mengkilap pada media EMBA yang ditunjukkan oleh panah berwarna hitam

Penghitungan bakteri dilakukan dengan metode total plating count. Penghitungan dilakukan berdasarkan sampel dan pengencerannya (L1-L12). Setelah dilakukan pemilahan cawan yang akan dimasukkan ke dalam perhitungan, jumlah koloni, faktor pengenceran cawan yang dipilih $\left(10^{-1}\right.$ atau $10^{-2}$ atau $\left.10^{-3}\right)$, dan volume yang diteteskan pada cawan $\left(10^{-3} \mathrm{~mL}\right)$ tersebut kemudian dimasukkan ke dalam rumus berikut:

Hasil perhitungan CFU/g pada setiap sampel kemudian dibandingkan dengan batas maksimum kontaminasi Escherichia coli yang telah ditetapkan oleh BPOM, yakni $3 \mathrm{CFU} / \mathrm{g}$. Hasil perhitungan koloni setiap sampel dalam $\mathrm{CFU} / \mathrm{g}$ dan status kontaminasinya disajikan dalam Tabel 2.

Perhitungan jumlah koloni Escherichia coli dalam CFU/g diatas menunjukkan bahwa sampel terkontaminasi kecuali sampel L3, L8, L9, dan L11. Sampel yang terkontaminasi melebihi batas kontaminasi yang telah ditetapkan BPOM.

\section{DISKUSI}

Hasil penelitian diatas bahwa dari 12 sampel yang diteliti terdapat 8 sampel (67\%) yang terkontaminasi Escherichia coli dengan rata-rata jumlah koloni $17 \times 10^{4} \mathrm{CFU} / \mathrm{g}$. Hasil penelitian ini serupa dengan penelitian tentang lawar putih di daerah Kuta dimana pada penelitian tersebut didapatkan 20 sampel $(46,5 \%)$ positif pada uji EMBA. ${ }^{7}$ Hasil penelitian lain pun menunjukkan kontaminasi Escherichia coli pada lawar putih sebanyak 100\% pada daerah kota Gianyar, dan Tabanan. Pada penelitian lain yang dilakukan pada lawar putih, hasilnya berbeda pada penelitian yang dilakukan pada lawar merah. Hasil penelitian pada lawar 
merah memiliki proporsi keberadaan Escherichia coli lebih tinggi dibandingkan dengan lawar putih. ${ }^{10}$ Pada penelitian lain yang mengkaji tentang pedagang lawar, sebagian pedagang yang higiene nya tidak baik terbukti pada lawar terdapat Escherichia coli. Pada makanan, keberadaan Escherichia coli merupakan sebuah keamanan pangan dimana tidak boleh terdapat pada sebuah makanan walaupun tidak semua jenis Escherichia coli akan mengakibatkan penyakit pada tubuh manusia. Keberadaan Escherichia coli menunjukkan kontaminasi saluran pencernaan pada hewan ataupun manusia. ${ }^{10}$

\section{SIMPULAN}

$67 \%$ dari total sampel lawar merah babi telah terkontaminasi oleh bakteri Escherichia coli dengan jumlah kontaminasi rata-rata adalah $17 \times 10^{4} \mathrm{CFU} / \mathrm{g}$ di kota Denpasar melebihi batas kontaminasi yang ditentukan BPOM yaitu $3 \mathrm{CFU/g}$.

\section{DAFTAR PUSTAKA}

1. Addis M, Sisay D. A Review on Major Food Borne Bacterial Illnesses. Journal of Tropical Diseases 2015;3(4).

2. BPOM. Laporan Tahunan Badan Pengendali Obat dan Makanan Republik Indonesia; 2011.
3. Florida FS, Wachni AH, Gaiserzj EE. Characterization of. 2007;22:25-32.

4. Buchanan RL, Doyle MP. Foodborne disease significance of Escherichia coli O157:H7 and other enterohemorrhagic E. coli. Food Technol. 1997;51(10):69-76.

5. Centers for Disease Control and Prevention. E. coli (Escherichia coli) [Internet]; 2015 [cited 2016 Nov 16]. Available from: https://www.cdc.gov/ecoli/general/index. html

6. Kruger V. Sacred Ceremonial Cuisine: Food of the Gods, Tuttle, North Clarendon; 2014

7. Trisdayanti PE. Higiene Sanitasi dan Potensi Keberadaan Gen Virulensi E. Coli pada Lawar di Kuta: Tantangan Pariwisata dan Kesehatan Pangan di Bali; 2015

8. Leininger DJ, Roberson JR, Elvinger F. Use of eosin methylene blue agar to differentiate Escherichia coli from other gram-negative mastitis pathogens. J Vet Diagnostic Investig. 2001;13(3):273-5.

9. Espinar MJ, Rocha R, Ribeiro M, Rodrigues AG, Pina-Vaz C. Extended-spectrum $\beta$-lactamases of Escherichia coli and Klebsiella pneumoniae screened by the VITEK 2 system. J Med Microbiol. 2011;60(6):756-60.

10. Suter IK. Studi Tentang Pengolahan dan Keamanan Lawar (Makanan Tradisional Bali). 1997;37-43.

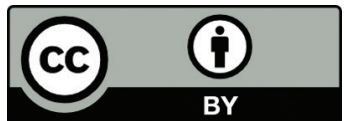

This work is licensed under a Creative Commons Attribution 